\title{
COVID-19: IMPACT ON HUMAN RIGHTS FROM THE HEALTHCARE PERSPECTIVE IN THE CASE OF PATIENTS TRIAGE
}

DOI: $10.36740 /$ WLek202108120

\author{
Karina Palkova' ', Juris Jansons ${ }^{2}$, Jānis Grasis ${ }^{1}$ \\ 'RIGA STRADINS UNIVERSITY, RIGA, LATVIA \\ 20MBUDSMAN OF THE REPUBLIC OF LATVIA, RIGA, LATVIA
}

\begin{abstract}
The aim: To analyse human right issues in health care during the SARS CoV-2 pandemic from the perspective of patients' and medical practitioner's rights.

Materials and methods: Multidisciplinary research will be conducted as part of national as well as international health care policy documents, international human right instruments, including case law decisions, and also major scientific articles on human rights from the healthcare perspective will be analysed. The comparative, Research synthesis method and systemic analyses will be made during the research.

Results: The study confirmed that human right issues in the context of health care in case of Patient triage become relevant and transformed. The situation of COVID-19 has created new precedents for human rights, with a particular impact on the rights of doctors and patients.

Conclusions: Human rights from the healthcare perspective become the topical issue during the COVID 19 pandemic. The legal practice in human rights had several transformations and it provides new challenges from patients as well as medical practitioners' rights. Important problem, from the ethical -legal perspective is the Patient's triage. The situation on patients triage or ranking shows importance and possibility of each member state to act fast, taking into consideration fast changing situation in medical health system. Sorting patients whose lives are at risk according to certain criteria for assessing their lives is not acceptable. In order to reduce events of violations of human rights during COVID 19 in healthcare, the emphasis should be placed for explanation of decisions made in state level.
\end{abstract}

KEY WORDS: health care, law, human rights, COVID-19 pandemic

Wiad Lek. 2021;74(8):1894-1899

\section{INTRODUCTION}

The spreading of COVID-19 infection and its consequences may be considered as one of the biggest challenges in the $21^{\text {st }}$ century on a global scale. The COVID-19 infection has affected aspects of peoples' daily life in all over the world and it has become a national and international problem. The COVID-19 situation has changed not only the public behavioural habits, but also local and international governance model, including the healthcare policy. Lack of experience in controlling the spread of COVID-19 infection has become an obstacle for fast and efficient solving of these problems, especially providing the healthcare services. Operational policies were developed in a national level, which allowed to act in emergency situation quickly and consequently, however considering the complicated situation also from a legal point of view, deficiencies occurred, which caused additional burden for rapid and efficient COVID-19 infection control policy.

Upon realization of developed COVID-19 infection spread control policy, each country faced the challenge, which is related not only to protection of public interests in general, but also compliance with and protection of the human rights of individuals. The legally consistent action is important in a context of combating any pandemic or epidemic. Besides an important issue in combating the spread of COVID-19 infection is the role of each individual, society in general, public and municipal institutions, private institutions. Therefore, upon the realization of necessary actions in combating the spread of COVID-19 infection, including, in the event of an emergency situation in the country, attention must also be paid to balancing the rights and interests of society (individuals) and the state, private institutions. The Institute for the Balancing of Rights between all parties also includes the obligation of all the above-mentioned parties to respect the human rights of the individual, despite the impact of COVID-19 on the national and international legal system as a whole. Need to note that the COVID-19 infection has affected several fields of rights, also field of human rights and medical rights, showing new challenges, precedents.

It should be noted that human rights in general guarantees to everyone the right to the highest attainable standard from the health perspective and impose an obligation to the states to take measures to prevent threats to public health. As well as international human rights documents impose an obligation to provide health care to those who need it. Besides, the international human rights standards shall be noted. They provide that in situations of important threats to society or public health or emergency case certain rights and freedoms restrictions are permissible. But the key issue 
is that these restrictions must be introduced in legal acts. Besides, the restrictions in particular situations must be based on non-discrimination principles and should be proportionate to the aim.

The key question, which will be viewed in the article, aims to determine whether COVID-19 infection can be legally used as an argument for restricting human rights in a specific healthcare context. At the same time the article will analyse how the rights and responsibilities of the patient and healthcare professionals have been transformed during the control of spread of COVID-19 infection.

\section{THE AIM}

The purpose of this paper is to analyse human right issues in health care during the COVID-19 pandemic from the patients and medical practitioner's rights perspective.

\section{MATERIALS AND METHODS}

This research is based on International, as well as European Union regulatory acts. The Latvian cases will be analysed during the research. Multidisciplinary research will be conducted as a part of national as well as international health care policy documents, international human rights instruments, including case law decisions and major scientific articles on human rights topic from the healthcare perspective. The comparative, synthesis and systemic analyses will be made during the research, statistical data, expert opinions, doctrinal ideas and reviews on this issue have been used.

\section{RESULTS}

The International Covenant on Economic, Social and Cultural Rights recognizes that everyone has the right to the highest attainable standard of physical and mental health. The document states that governments must take effective measures to prevent and treat epidemic, endemic, occupational and other diseases and fight against them [1]. The health is a fundamental human right indispensable for the exercise of other human rights [1]. The abovementioned is related to the patients and also medical practitioners. It can be noted, that this right is usually mentioned at national level as well. For instance, Article 93 of the Satversme (Constitution) of the Republic of Latvia, states that the right to life of everyone shall be protected by law [2]. Patients', as well as medical practitioners' rights from the human rights perspective became one of the topical issues in COVID-19 pandemic time. It must be noted that to deal with the difficult situation even from the legal point of view many governments, as well as private sector (institutions) have introduced new regulations that can help to solve the current situations connected to COVID-19 infectious disease control and prevention in general. According to abovementioned several problematic positions can be identified that shows how new socio - legal situation may affect individual rights in different areas. According to
World Health Organization Constitution the highest attainable standard of health as a fundamental right of every human being must be protected. Besides the World Health Organization shows the necessity to understand health as a human right that creates a legal obligation on states. Moreover, the World Health Organization provides the state importance from the particular rights protection and states that every state has the obligation to give the support to the right to health [3]. It should be noted, that the World Health organization protects the right to health and says, that this right shall be enjoyed without discrimination on the grounds of race, age, ethnicity or any other status [3]. The term "any other status" is wide and according to the case law means any status of individual that can bring the ground of discrimination. So, the position at work, the social status, disability, state of health, political or other conviction, national or social origin etc.

According to the international documents in the field of human rights, as well as the World Health organization the right to health consists of two main elements - freedom and entitlements.

In the case of human rights protection from the patients and medical professionals' perspective the important role must be paid to entitlements, which in common include the right to a system of health protection. And that system gives an equal opportunity to enjoy the highest attainable level of health to an individual [4].

The COVID-19 situation shows that in order to protect the individuals as well as society in common it is necessary to act in unordinary way, which can deal with the challenges from the human rights perspective. According to Article 1 of the Universal Declaration of Human Rights of Nations Organization, adopted in 1948, all human beings are born free and equal in dignity and rights [5]. They are endowed with reason and conscience and should act towards one another in a spirit of brotherhood. At the same time Part one and two of Article 29 of the COVID-19 Declaration states that each person shall have obligations to society, in which only the free and complete development of his personality is possible, upon realization of his/her rights and freedom, every person shall obey the restrictions stipulated by law only, the sole purpose of which is to ensure the proper recognition and dignity of the rights and freedoms of others and to meet the fair demands of morality, public order and general welfare in a democratic society. Actually the restriction of human rights means delimitation of human rights in particular situation, including the situations, which affect a field of health care and patients' and medical practitioners' rights. According to the International Covenant on Civil and Political Rights of 1966, the International Human Rights Law provides several principles, when the restrictions of individual rights can be accepted. But the aim must be clear - to protect public health. The important note is that the restriction of the rights must be proportionate and non-discriminatory $[7,8]$.

The emergency situation shall not be a reason for restriction of human rights, need to remind that restriction of rights stated in the European Convention for the Protection 
of Human Rights and Fundamental Freedoms were and still are reality of citizens of the member stated of the European Council [8]. Article 15 of the Convention provides the regulation in case of derogation in time of emergency. Article 15 of the Convention allows reasonable deviations from the compliance with norms of convention, however the rights included therein shall be interpreted narrowly, allowing the retreat from commitments only as much as the exceptional nature of the situation inevitably requires. Restrictions are allowable and even necessary, however, we need to remember that human rights are not cancelled. Besides need to note that in the event of residents consider that their rights are restricted disproportionately, resident shall not lose their right to address individual complaints to law enforcement authorities, for example, police office, prosecutor's office or court, etc. $[8,10]$. The same can be written by analogy with regard to the restriction of patients' and medical treatment rights during COVID-19.

Upon analysis of the situation during spread of COVID-19 infection in general several problem issues of a practical nature may be highlighted, which are related to compliance with patients' and medical practitioners' human rights in a context of healthcare.

During the spread of COVID-19 infection the issue and concern about sorting patients according to different characteristics has become topical in the world. For example, in the event of the number of free spaces in health care institutions is limited, should not the persons over the age of 75 with chronical diseases and other patients with severe illnesses be treated with all available means so more younger and less sick persons could have access, possibly, for life saving therapy. At the same time the issue on patient sorting may be analysed also in the event of vaccination. Namely, in the event, when the country determines groups of persons, who have primary rights to apply for vaccination, aren't there discriminated some groups of patients and also medical practitioners? This issue may be revised from an ethical and human rights perspective.

The topicality of the issue was highlighted in Italy. Medical practitioners and patients in Italy were the persons who faced the problem. Italy was one of the first countries where a large number of patients, who were critically ill at the same time, and which led to a shortage of intensive care resources $[8,9]$.

The World Health Organization identifies the ethical problem and states that there is a need for guidance to ensure the ethical conduct of decision-making process in clinical care, and public health policymaking at every level of the global COVID-19 response [11]. The UNESCO International Bioethics Committee made the research on the ethical consideration of the decision to select the patients, when there is a shortage of resources. The Article 5 of the documents states that COVID-19 clearly exposes the strength and weaknesses of the healthcare systems in different countries. Obstacles and inequities of access to healthcare play a special role [10]. Besides the document provides information that the allocation of resources, as well as strong public health system must be the main agen- da of each country, however the common or international cooperation is needed [10].

This document highlights the importance of ethical issues when the decision on patients triage shall be made. During the COVID-19 infectious disease control, more and more topical become the issues what kind of patients will be in the "first line" to receive the health care in the situation where the demand for access to treatment increases exponentially.

When the decision on patient selection should be taken, some clear procedures are needed. But the difficult part is that the procedures must respect human dignity. The ethical principles or procedures for patients triage must be overviewed form the human rights framework. The protection of patients', medical practitioners' etc. right to health as rights of human being must be respected. It must be noted that Article 14 of the UNESCO Universal Declaration on Bioethics and Human Rights states that the promotion of health and social development for their people is a central purpose of governments that all sectors of society share [9]. Besides, the Declaration states that the highest attainable standard of health is closely connected to fundamental right of human being (for instance, as well patients, medical practitioner etc.) and provides the access to the highest available healthcare [9].

The abovementioned clearly states the range of responsibilities of the state regarding provision of rights in the field of health. However in situations of COVID-19 patients triage it is important that not only patients, but also medical practitioners understand the basic elements, which determine the principles of patients' triage. There is no doubt that the mentioned principles arise from human rights, including, considering the legal and ethical aspect [13]. Therefore the definition of the term "patients' triage" is a challenge from legal, ethical and also scientific perspective. It is practically impossible to determine human rights inherent for each person. There are different versions, what is exactly assessed, when the decision on patients' triage is made. One of opinions is based on the fact that all patients with a comparable prognosis must have the same access to necessary health care in the case of a crisis, for instance, COVID-19, and this should be based on predefined medical and ethical criteria [14]. But what happens in the case when there are several patients with the same comparable prognosis, but in practice the limits for necessary therapy exist. Some theories provide "first come" or randomization approach. But, how does this approach deal with the human rights? Medical practitioners are the persons who must make the decision, as well as must undertake all risks for this decision. If there are no clear criteria of provision, the risk become higher. From the medical practitioner's point of view there are additional risks that are taken regarding the patient's safety. From the patients' rights point of view, there is a situation when one person's rights become more discriminated. The Article 1 of the Universal Declaration of Human Rights states that all human beings are born equal in dignity and rights. From this perspective, as well as taking into consideration other human rights aspects, Patient 
triage is the huge problem for the medical practitioners' and patients' rights [5]. Medical practitioners should take the decisions in the COVID-19 situation, but the regulations or guidelines are very theoretical and debatable. Another approach to patients' triages and particular criteria is based on distribution, such as preferential treatment. But these criteria are usually rejected on the ground of social role and social roles and societal implications. [12].

Hence, the setup of criteria that can help to deal with Patients' triage issues is challenge for medical practitioners, lawyers etc. COVID-19 pandemic highlights the potential reality from the future perspective. The healthcare system in international level must be ready for extremely fast reactions in similar cases. A lot of unordinary and previously unused procedures are needed in a very short period of time. The fast reaction on justification of the decision burden in the case of Patient triage should be clear and based on ethical, legal standard, which is based on main principles of human rights.

From the one hand Patient triage process is related to difficult decision making process, on the other hand, as was mentioned above, each country can prevent current situation. The activity of each country and political reaction from the health care policy making perspective is important mechanism for qualitative, effective anti-Patient triage system. Triage process in general is related to insufficient resources. As insufficient resources we can understand human resources, (for instance, medical practitioners) or technical resources (for instance, medical equipment, COVID vaccines etc.). The role of management is to be thoughtful on behalf of the state. The policy of each state and rapid response capability helps to reduce the risks.

In conclusion, it shall be noted, that Patient's triage can be acceptable in the case of COVID-19 pandemic. But all parties involved in to the decision-making process (direct or indirect involvement) must act in accordance with the best ethical, legal standards, which must be based on human rights. The medical practitioners should not be the persons who take all risks in such situations $[15,16]$. The clear, understandable provisions, guidelines must be provided for them. Medical practitioners are acting to achieve and maintain the highest professional, ethical standards. And state, state institutions, researchers, lawyers, international organizations should provide support in this complicated documentation related to specific standards and human rights. Patients as medical practitioners have the rights had duties as well. The duties of the patients usually are regulated on the national level. Patients' behaviour, as well as medical practitioner's behaviour affects the public health [16]. The obligation to protect the public health can be founded in state constitutions or national legal acts. To protect public health, as it was mentioned above, state may restrict the fundamental rights of certain persons, as well as patients' rights. It can be noted, that the measures implemented by each state in the field of public health, including the protection of public welfare, is the unique competence of the state. The protection of public health is closely related to public security issues, and hence, to protect this, state in the face of a pandemic and a significant threat to public health, can act to prevent the danger and normalize the situation. In case the Patient's triage is vital, need to ensure that the restriction of rights necessarily deals with the public security protection. Depending on the intensity of the threat, each state is able to choose different legal mechanisms for regulation of the situation. In order to act successfully and to protect public interests and safety a special legal regime can be declared - an emergency situation or a state of emergency. But, of course, the state can also adopt different regulatory enactments, which are provided for a special settlement to overcome the situation while maintaining the normality regime [15]. Convention for the Protection of Human Rights and Dignity of the Human Being with regard to the Application of Biology and Medicine: Convention on Human Rights and Biomedicine must be mentioned. Article 1 of the convention states that parties of this Convention shall protect the dignity and identity of all human beings and guarantee it for everyone (patients, medical practitioners etc.) without discrimination, respect for their integrity and other rights and fundamental freedoms with regard to the application of biology and medicine. [17].

\section{DISCUSSION}

In 2020 the Committee on bioethics has published Statement on human rights considerations relevant to the COVID-19 pandemic. According to the document, it is essential that all decisions in case of restriction of the rights of individuals during the COVID-19 should meet the fundamental requirements in respect of human dignity and that human rights are upheld [13]. Besides, Convention for the Protection of Human Rights and Dignity of the $\mathrm{Hu}$ man Being with regard to the Application of Biology and Medicine: Convention on Human Rights and Biomedicine Article 26 states that no restrictions shall be placed on the exercise of the rights and protective provisions contained in this Convention other than which are prescribed by law. Other criteria are related to the necessity to protect democratic society in the interests of public safety, for the prevention of public health, or for the protection of the rights and freedoms of others [18 ].

Besides, the Universal Declaration of Human Rights provides that everyone has the right to life, liberty, and security of persons. This provision can be understood as medical practitioners' rights to protect themselves, society, patients etc. from the potential risks. European Convention on Human Rights states that everyone's right to life shall be protected by law. From the one hand it means that an individual should be the final who can decide relating to their life, body, health. On the other hand, the ethical issues still are in the centre of discussions. Nevertheless, therefore, there is a legal basis from which to derive a state right to Patient's triage.

From the international public law perspective, the international legal documents are structured on the ground of sovereignty of each country. Nevertheless, the state legal 
power is restricted, it has some limitation. For example, several restrictions, which are based on convention of international human rights.

\section{CONCLUSIONS}

In general, human rights from the healthcare perspective become the topical issue during the COVID 19 pandemic. The legal practice in human rights had several transformations and it provides new challenges from patients as well as medical practitioners' rights.

The right to health is one of the rights, which have been violated during the COVID 19. Insufficient or untimely provided medical care can be mentioned, and also the absence or insufficient number of personal protective equipment for patients, as well as medical practitioners can be mentioned. Important problem, from the ethical -legal perspective is the Patient's triage. The situation on patients triage or ranking shows importance and possibility of each member state to act fast, taking into consideration fast changing situation in medical health system. Sorting patients whose lives are at risk according to certain criteria for assessing their lives is not acceptable. This means that they must not be sorted by age or by other criteria such as material status, education, social status, etc. An analogy with exceptional cases (classical case - soldier during the war) where a doctor can decide that a person in the extreme situation must sacrifice his life for the benefit of another person, does not work during the COVID19. If the sorting of people's lives on the basis of age (or other criteria determining the value of life) to save the lives of others is allowed by state, then such treatment would be incompatible with Article 93 of the Satversme (Constitution) of the Republic of Latvia, which states that the right to life of everyone shall be protected by law.

Another important element in the case of successful management of the COVID 19 pandemic prevention is the communication with patients as part of society. When patients' rights to freedom, life and health are violated or pretend to be violated, patients may become proactive and try to protect their interests and rights. The scope and quality of the information about the restrictions of their rights must be clear and explained in details from the part of institution or state.

In order to reduce events of violations of human rights during COVID 19 in healthcare, the emphasis should be placed for explanation of decisions made in state level. States should show that they are open to provide explanation and meaningfulness of decisions made. It is important for public to understand, why they should comply with and execute the decisions made. The meaningfulness of restrictions, which is insufficiently explained, creates the public resistance to their implementation.

Public interests sometimes are translated widely and vaguely. It is not clearly explained, what exactly public interests are provided by Covid-19 infection control legislation. In the public space the range of restrictions prevails, not information explaining the legitimate and practical purpose of the restrictions by the state authorities. Basically as the only target is highlighted - elimination of epidemic crisis, but such national safety aspects as economic sustainability and well-being of population are left without sufficient attention, which consequently would be endangered without elimination of epidemic crisis, which also reduces the efficiency of adopted restrictions. Particular attention should be paid to explaining the proportionality of the limitation of civil rights, as not only the patients, but also medical practitioners shall be sure that not all restrictions in both - patient sorting context and in context of performance of tasks and information, and also in context of basic freedom of human rights shall not be recognized as excessive.

\section{REFERENCES}

1. International Covenant on Economic, Social and Cultural Rights. United Nations. Available from: https://www.ohchr.org/EN/ Professionallnterest/Pages/CESCR.aspx [reviewed 2021.03.03].

2. The Constitution of the Republic of Latvia. Constitutional Assembly. Available from: https://likumi.lv/ta/en/en/id/57980 [reviewed 2021.03.03].

3. World Health Organization, 2017. Human rights and health. Available from: https:// https://www.who.int/news-room/fact-sheets/detail/ human-rights-and-health [reviewed 2021.03.04].

4. Economic and Social Council "Substantive issues arising in the implementation of the international covenant on economic, social and cultural rights General Comment No. 14 (2000) "The right to the highest attainable standard of health (article 12 of the International Covenant on Economic, Social and Cultural Rights)", United Nations. Available from: https://digitallibrary.un.org/record/425041?ln=en [reviewed 2021.03.04.].

5. Universal Declaration of Human Rights of United Nations. Unated Nations. Available from: https://www.un.org/en/universal-declarationhuman-rights/ [reviewed 2021.03.04].

6. United Nations, 2009. Economic and Social Council "General Comment No. 20 Non-discrimination in economic, social and cultural rights (art. 2, para. 2, of the International Covenant on Economic, Social and Cultural Rights)"Available from: file:///C:/Users/karpal/Downloads/G0943405. pdf [reviewed 2021.03.04.].

7. World Health organization, 2020. Ethics and COVID-19. Available from: https://www.who.int/teams/health-ethics-governance/diseases/ covid-19 [reviewed 2021.03.04].

8. European Council, 1950. Convention for the Protection of Human Rights and Fundamental Freedoms. Available from: https://www.echr.coe.int/ documents/convention_eng.pdf [reviewed 2021.03.04].

9. United Nations, 2005. Universal Declaration on Bioethics and Human Rights. Available from: http://portal.unesco.org/en/ev.php-URL_ ID $=31058 \&$ URL_DO=DO_TOPIC\&URL_SECTION $=201 . \mathrm{html}$ [reviewed 2021.03.04].

10. United Nations, 2020. Statement on COVID-19: ethical considerations from a global perspective. Statement of the UNESCO International Bioethics Committee (IBC) and the UNESCO World Commission on the Ethics of Scientific Knowledge and Technology (COMEST). Available from: https://unesdoc.unesco.org/ark:/48223/pf0000373115?fbclid= IwAR3CZBIdVi_r--TUoNLs0qWHuwyNIhZiBdK4z5LfdeZIZ9FBiw1EG0h f3JQ [reviewed 2021.03.04].

11. World Health organization, 2020. Ethics and COVID-19. Available from: https://www.who.int/teams/health-ethics-governance/diseases/ covid-19 [reviewed 2021.03.04]. 
12. Jöbges S, Vinay R, Luyckx VA, Biller-Andorno N. Recommendations on COVID-19 triage: international comparison and ethical analysis. Bioethics. 2020;34:948-959. https://doi.org/10.1111/bioe.12805

13. World Health Organization, 2020. Mask use in the context of COVID-19. Interim guidance. Available from: https://www.who.int/publications/i/ item/advice-on-the-use-of-masks-in-the-community-duringhome-care-and-in-healthcare-settings-in-the-context-of-the-novelcoronavirus-(2019-ncov)-outbreak [reviewed 2021.03.04].

14. Council of Europe, 1997. Convention for the Protection of Human Rights and Dignity of the Human Being with regard to the Application of Biology and Medicine: Convention on Human Rights and Biomedicine. Available from: https://www.coe.int/en/web/conventions/full-list/-/ conventions/rms/090000168007cf98 [reviewed 2021.03.04].

15. The 0 mbudsman of the Republic of Latvia. 2021. Face masks and Covid 2019. https://www.tiesibsargs.Iv/news/Iv/jautajumi-un-atbildes-parcilvektiesibu-apsverumiem-sejas-masku-ierobezojumu-noteiksana [reviewed 2021.03.04].

16. Burlacu A, Crisan-Dabija R, et. el.. , 2020. Pandemic lockdown, healthcare policies and human rights: integrating opposed views on COVID-19 public health mitigation measures. doi:10.31083/j.rcm.2020.04.274

17. Council of Europe, 1997. Convention for the Protection of Human Rights and Dignity of the Human Being with regard to the Application of Biology and Medicine: Convention on Human Rights and Biomedicine. Available from: https://www.coe.int/en/web/conventions/full-list/-/ conventions/rms/090000168007cf98 [reviewed 2021.03.04].

18. Buchanan B. J., 2020. Covid-19 and the First Amendment: A running report (July 27). Available from: https://www.mtsu.edu/firstamendment/post/613/covid-19-and-the-first-amendment-a-run ning-report-may-21 [reviewed 2021.03.04].
This research is funded by the Ministry of Education and Science of the Republic of Latvia, within the project "Life with COVID-19: Evaluation of overcoming the coronavirus crisis in Latvia and recommendations for societal resilience in the future," project No. VPP-COVID-2020/1-0013.

\section{ORCID and contributionship:}

Karina Palkova: 0000-0002-6909-571X ${ }^{A, B, D}$

Jānis Grasis: 0000-0002-1394-9958 ${ }^{B, D, F}$

Juris Jansons: 0000-0002-1394-9958 B,D,E

\section{Conflict of interest:}

The Authors declare no conflict of interest.

\section{CORRESPONDING AUTHOR \\ Karina Palkova}

Riga Stradins university

16 Dzirciema st., 1007 Riga, Latvia

e-mail: karina.palkova@inbox.lv

Received: 12.03.2021

Accepted: 06.07.2021

A - Work concept and design, B - Data collection and analysis, C - Responsibility for statistical analysis, D-Writing the article, $\mathbf{E}$-Critical review, $\mathbf{F}$ - Final approval of the article 